English, French, Russian and Spanish. As the conference will last only twelve working days, there will not be time for all papers to be presented orally. The choice of those to be read to the conference, in full or in part, will be made by a panel of qualified scientists to be designated by Mr. Hammarskjold on the advice of the advisory committee. Papers which are not presented orally will still be considered part of the conference, and will be included in its published proceedings.

\section{Public School and Grammar School Boys for Industry}

Following the pamphlets recently issued on careers for university graduates in industry and directing the attention of industry in Britain to the growing importance of the universities as a recruiting ground for the ablest talent in each generation of school-leavers (see also p. 313), the Education Committee of the Federation of British Industries has now prepared a further pamphlet on the recruitment and training of the public school and grammar school boys in industry (pp. 12. Fed. of British Industries, London, 1954. 1s.). The pamphlet suggests that industry is in danger of neglecting an important source of managerial talent, and it makes detailed proposals as to the way in which firms able to offer posts suitable for public school and grammar school boys could summarize information regarding such posts and training on a standard index card for distribution to the appropriate schools. This distribution could be made direct to any schools with which the firm has already established contact, or with the co-operation of the Central Youth Employment Executive and the Public Schools Appointments Bureau.

The pamphlet points out that educational changes since the Second World War have led to many more grammar school boys in Britain remaining at school until they are seventeen or eighteen, while to-day 17 per cent of the total number of boys in the secondary schools are educated in grammar schools compared with 11.5 per cent in 1938. The selection procedure appears to be reasonably effective and, broadly speaking, the best intellectual talent in the secondary schools of England and Wales is to be found in the grammar schools, and, in Scotland, in the senior secondary school. Accordingly, industry can no longer count on recruiting from the elementary school leavers a sufficient number of those possessing the intellectual capacity and character demanded of foremen, departmental superintendents, managers or directors. Since at present 18 per cent of grammar school boys leave at 15,48 per cent at 16 , and 34 per cent between 17 and 19, there is still a large proportion of them, and of public school boys, available for recruitment at an age when industry is in direct competition with the Civil Service and other professions. Schoolmasters, in general, are probably less familiar with the prospects in industry, and the pamphlet is designed to dispel lack of knowledge which is leading industry to misuse valuable recruits.

\section{Metallurgical Developments at Swansea}

Metallurgy is an applied science, and in the words of Prof. R. Mehl is "a composite of learning and of abilities-to-do". As a university subject, like medicine, it is based on the pure sciences, which form the main part of the curriculum in the intermediate and subsidiary years. The reduction of metal from ore has been receiving a great deal of scientific study; but it is felt that the manipulation and utilization of the reduced metal itself requires increased attention and in the widest field. Metallic parts for modern structures frequently involve expensive engineering operations, but by the co-operation of the metallurgist, the engineer and the physicist, metallurgical short-cuts may be provided. A scientific study of fabrication processes on a suitable scale may cure existing troubles and lead to improved techniques. This involves a type of physical metallurgy which can be called 'fabrication metallurgy'. It would cover welding and joining, precision casting, extrusion, powder metallurgy and mechanical deformation. The Steel Company of Wales and Richard Thomas and Baldwin, Ltd., have together made a munificent gift, totalling $£ 100,000$, to the University College of Swansea to develop work along these lines. Certain portions of the existing courses will be amplified, and students may be able to select alternative lines of study in their last year. The introduction of postgraduate courses is being considered. Laboratory extensions are in hand and research fellowships are contemplated. A professor of physical metallurgy will be appointed within the existing Department, to deal with the teaching and research which this development involves.

\section{Charles Blachford Mansfield (1819-55)}

A PIONEER in the aniline industry, Charles Blachford Mansfield, died one hundred years ago on February 26,1855 , a martyr to science. He was born at Rowner in Hampshire on May 8, 1819, and was educated at Winchester and Cambridge, where he took his B.A. degree in 1846. At the newly founded Royal College of Chemistry in London he became the favourite pupil of the superintendent, August Wilhelm von Hofmann, under whose direction he found coal-tar naphtha to be an abundant source of benzene. Benzene had lately been found in coal-tar and named by von Hofmann. By freezing a carefully fractioned sample of coal-tar naphtha, Mansfield in 1849 obtained with the aid of simple dephlegmators a pure benzene distilling below $100^{\circ} \mathrm{C}$. which was a prerequisite for the aniline industry. In a pamphlet, "Benzol, its Nature and Utility", he mentioned that a peculiarly brilliant light could be produced by charging air with its vapour. During the 1849 cholera epidemic he advocated a pure water supply for Bermondsey and other districts. Interested in aeronautics, he wrote a book on "Aerial Navigation", which contained a number of remarkable forecasts. In his lectures on the chemistry of metals, delivered at the Royal Institution in 1851-52, he attempted a classification of his own devising. In 1852 he visited Paraguay and drew up a scheme for the colonization of the Gran Chaco. He pointed out the wastage of beef and other animal matter, which could be used for making ammonia or saltpetre, and suggested that the vast stores of timber wasted might be turned into huge unsinkable rafts across the Atlantic. Mansfield's chief contribution to theoretical chemistry was his "Theory of Salts", published in 1855. He was engaged in preparing samples of benzene for the Paris Exhibition, when on February 17, 1855, a naphtha-still in his laboratory at St. John's Wood overflowed. Severely burned, he died nine days later at the Middlesex Hospital, at the early a.ge of thirty-six.

\section{Catalogue of Optical Instruments}

$\mathrm{NEW}$ illustrated editions have recently been issued of Sections $D$ and $M$ of the "Hilger General Cata- 